\title{
Opportunities to Alleviate Soil Acidity Impact Through Exploitation of Diverse Liming Materials Integrated with Different Phosphatic Fertilizer Sources in Ethiopia
}

\author{
Matias Dejene \\ Ethiopian Institute of Agricultural Research, Holeta Agricultural Research Center P.O. Box 31, Natural \\ Resources Management Research Program
}

\begin{abstract}
Several research activities were conducted to improve the productivity of degraded and less fertile soils of Ethiopian, among the most crop yield-limiting essential nutrients phosphorus is the major ones next to nitrogen moreover which is sourced from non-renewable natural resource and its limited reserve will vanish within few decades if the world fertilizer consumption will continue as it is. Phosphorus deficiency and losses problem is more sensitive in acidic soils which are widely spread in southern, western, southwestern, northwestern, and most of central Ethiopia its level becomes even more worst. Consequently, seeking multiple ways of improving the nutrient use efficiency and minimizing losses to the environment should be considered. Several forms of phosphorus fertilizers were commonly used which includes organic and inorganic forms it has its own merits and demerits on the efficient uses of phosphorus for crop production. Optimizing soil $\mathrm{pH}$ is crucial for acidic soil by using lime (CaCO3) and other different liming materials like farmyard manure, vermicompost, and biochar as an alternative it's also possible to improve soil $\mathrm{pH}$ by direct application of rock phosphate and partially acidulated fertilizer products on acidic soils which minimize the cost which was incurred for acidulation process on industrial fertilizer production. On the other hand, using blended lime with the most limiting essential nutrients based on soil fertility status will improve both efficiency and application costs with other multiple advantages over the classic ones.
\end{abstract}

DOI: $10.7176 / \mathrm{JNSR} / 12-7-02$

Publication date: April $30^{\text {th }} 2021$

\section{INTRODUCTION}

Among major Essential Nutrients which needs special attention for the welfare of all life forms on Earth, phosphorus takes leading line since its demand were vastly increasing whereas the supply or it's reserve become depleted which is non-renewable by its nature D.Cordell et al., (2009). On the other hand, edaphic factors like soil fertility degradation erosion and soil acidity aggravation has a vital role in malfunctioning of healthy biogeochemical cycle of phosphorus. Phosphate fertilizers are produced from rock phosphate (RP). About $80 \%$ of the RP mined annually is used for fertilizer production and, considering the current level of worldwide consumption, it is expected that reserves will vanish in three centuries time (Roberts et al. 2015; USGS, 2019). Most of the remaining phosphate rock reserves are controlled by Morocco, China and US. Mining, transporting and consumption of RP will be more challenging. The possibility of exhaustion of this resource may compromise global food production (Jarvie et al. 2015).

Most tropical regions soils have usually low levels of plant available $\mathrm{P}$, which is a result of adsorption and precipitation reactions, and its high affinity with soil constituents Shen et al. (2011) which leads to limited phosphorus availability, almost all agricultural production is highly dependent on the use of phosphorus fertilizers. This nutrient is absorbed by plants in the soil solution as a monovalent anion orthophosphate $\left(\mathrm{H}_{2} \mathrm{PO}_{4}{ }^{-}\right)$ and divalent $\left(\mathrm{HPO}_{4}{ }^{2-}\right.$ ), each representing equal proportion of total phosphorus at a $\mathrm{pH}$ close to neutral. Whereas at acidic soil $\mathrm{pH}$ from 4-6, the monovalent $\mathrm{H}_{2} \mathrm{PO}_{4}$ is represented nearly all of the total phosphorus in soil solution Ana paula et al. (2020) due to higher concentration of $\mathrm{H}^{+}$ion in acidic soil solution.

The most used phosphate sources in agriculture are those that are highly water soluble, with fast dissolution in the soil which favors precipitation and adsorption. Approximately three days after the application of these sources in the soil, a large part of their P is transformed into non-labile forms (pagliari et al. 2010; Rajput et al. 2014) substantially reducing their efficiency when applied to crops. Consequently, looking for a sort of approaches which can cop up with such harsh acidic soil conditions for the country like Ethiopia is important to reduce the adverse effect which becomes aggravated due to different anthropogenic and natural factors; to optimize the expense which were spent for acquiring and transporting such bulky liming materials and fertilizers, with regard to sustainable soil fertility restoration and optimal natural resource utilization with environmentally sound approaches. 


\section{SOIL ACIDITY AND ITS WORLDWIDE DISTRIBUTION}

It is estimated that acid soils occupy about 3.95 billion ha of land area, i.e., about $30 \%$ of the ice-free land area of the world (Uexkull and Mutert, 1995). In FAO soil classification system (FAO, 1988) acid soils are grouped under Feralsol and Acrisols and to a lesser extent to Plinthisols, Alisols and Nitisols they are covered more than one third of Sub Saharan Africa SSA (Valentin et al., 1991). Acidity is defined as the ability of chemical compounds to split out of protons in solution. Correspondingly the concept of the "acidity of soils" may be defined as soils' peculiarity to sustain a certain number of protons in solution or the concentration of hydrogen ions in the soil solution (Fageria and Baligar, 2003). The concentration of $\mathrm{H}^{+}$comes in units of milligramequivalents and is measured on the $\mathrm{pH}$ scale, as the negative logarithm of $\mathrm{H}^{+}$activity in a solution (Foth, 1984).

Exchangeable acidity is the amount of acid cations $\left(\mathrm{Al}^{3+}\right.$ and $\left.\mathrm{H}^{+}\right)$occupied on the cation exchange capacity $(\mathrm{CEC})$ which is a total amount of cation, capable of equivalent exchange with cations contained in a solution that interacts with soil (Fenton and Helyar, 2007). It comes in units of mg-eq per 100 grams of soil or per $1 \mathrm{~kg}$ of soil. Exchangeable positions of loamy minerals are formed mainly through isomorphic substitution $\mathrm{Si}^{4+}$ for $\mathrm{Al}^{3+}$ (on tetrahedron silicate clay) and/or $\mathrm{Al}^{3+}$ for $\mathrm{Mg}^{2+}$ (on octahedron structure) their quantity does not depend on the medium reaction. Exchangeable acidity is calculated during the treatment of soil with a neutral salt solution $\mathrm{Al}$ (Allen et al, 2007).

$\left.\mathrm{SAC}) \mathrm{H}^{+}+\mathrm{KCl}_{\mathrm{s}} \rightarrow \mathrm{SAC}\right) \mathrm{K}+\mathrm{HCl}_{\mathrm{s}}$

$\left.\mathrm{SA}) \mathrm{Al}^{3+}+\mathrm{KCl}_{\mathrm{s}} \rightarrow \mathrm{SAC}\right) \mathrm{K}+\mathrm{AlCl}_{3 \mathrm{~s}}+3 \mathrm{H}_{2} \mathrm{O} \rightarrow \mathrm{Al}(\mathrm{OH})_{3}+3 \mathrm{HCl}_{\mathrm{s}}$

Where: SAC soil adsorption complex, $s$ - soil solution

\subsection{State of Soil Acidity in Ethiopia}

Perilous increase on soil acidity in Ethiopia leads to reduced crop yields, poor plant vigor, stunted root growth, poor nodulation of legumes, uneven crop and pasture growth, dominance of acid-tolerant weed species like Geranium, increased incidence of diseases and abnormal leaf color (Duffera and Robarge, 1999). Acid soils occur widely in Ethiopian highlands, where the rainfall intensity is high and crop cultivation has occurred for many years (Taye and Höfner, 1993). Crops differ in their susceptibility to soil acidity, the pH ranges of soils for best crop yields is considered to be between 6.5 and 7.0. Wheat, barley, maize, clover and beans grow well on neutral to mildly acid soils with a $\mathrm{pH}$ of 6-7 (IFA, 1992). Soil quality degradation with respect to acidity is mainly an inherent problem due to the weathering process of the soil as opposed to problems caused by manmade. However, sub-soil acidity as a result of the removal of surface soils by erosion is most common in warm, humid areas where soils are disturbed by humans (Schlede, 1989). Soil surveys of Ethiopia show that the soils of large areas of western and south western Ethiopia are acidic, with pH values below 5.5 (EthioSIS, 2014). The extent of acid soils is estimated to be $28 \%$ of the total area, and those that are strongly acidic (with a pH of 4.1 5.5 ) are estimated to be $7 \%$ of the total area and $21 \%$ of it was moderately acidic soil with pH ranges from 5.6 6.5 .

\subsection{Acid Soil Management}

Soil amendments are anything mixed into topsoil to promote healthy plant growth, they function in several ways, for example, they may moderate the $\mathrm{pH}$ of soil or supply nutrients (Fageria and Baligar, 2007). Soil conditioners like composted manure, improves soil structure by binding soil particles into larger aggregates. This increases the amount of pore space and enhances air exchange, water movement, and root growth (Bell and Bessho, 1993). The forms of aluminum are mostly exchangeable $\mathrm{Al}^{3+}$ under very acidic conditions $(\mathrm{pH}<4.5)$ to aluminumhydroxyl ions at higher $\mathrm{pH}(4.5-6.5)$ (Carson and Dixon, 1979). The exchangeable $\mathrm{Al}^{3+}$ precipitates as insoluble $\mathrm{Al}$ hydroxyl species as $\mathrm{pH}$ increases and is reported to decrease thousand-fold for each unit increase in $\mathrm{pH}$. However, at $\mathrm{pH}$ values greater than 6.5 , Al becomes increasingly soluble as negatively charged aluminates form (Haynes, 1984). The $\mathrm{Al}(\mathrm{OH})_{3}$ species is of minor importance and exists over only a narrow pH range. Research has shown that with liming and proper use of organic amendments, marginal lands can be restored to high productivity (Hornick and Parr, 1987). Soils with a $\mathrm{pH}$ of $<5.5$ usually have problems of Al toxicity or acidification, but they can be improved with lime, compost or organic manure (Scherr and Yadav, 1996). Up on liming many authors have reported decreases of $\mathrm{Al}$ in the soil solution as well as in the exchangeable complex (Alvarez et al., 2009), improve soil structure, significant yield increases (Buri et al., 2004), increase in p uptake by plants (Fageria and Baligar, 2003).

Different crop species have varied range of $\mathrm{pH}$ optima, legume crops are relatively sensitive for acidity than cereal crops whereas cereals by itself have different $\mathrm{pH}$ optimal ranges and soil acidity tolerance as maize $>$ rye $>$ triticale $>$ wheat $>$ barley (Polle and Konzak, 1985). It now seems quite straight forward to try to adjust $\mathrm{pH}$ in a given soil to meet this specific requirement of the plant population that we seek to optimize the growth conditions for. However, it is far from being that simple adjustment of soil $\mathrm{pH}$ is always a compromise between soil aggregate stability (texture), plant requirement and the economic cost/benefit of liming all these factors have to be considered. Integrated approach involving liming, cultural practices and plant tolerance will probably be 
necessary, particularly where the acidification potential is high and its effect likely to extend into the subsoil (Bolan and Hedley, 2001).

Soils rich in organic material and clay soils represent the extremes with ideal $\mathrm{pH}$ values of 5-6 and 7.5-8, respectively. If we try to grow e.g. barley on both soils, we would probably succeed most likely not with the same good results but still we would obtain different grain yields. We should not try to adjust soil pH to 5.9 which is the optimum for barley in the clay soil with e.g. $\mathrm{pH} 7.5$ and a humus rich soil with e.g. pH 5. It would require huge amounts of lime or acidifying material and destroy soil structure in the clay soil (Haynes and Naidu,1998). Thus, liming is basically intended for a fine tuning of soil $\mathrm{pH}$ in light and moderately light soil and should only in rare occasions and with extreme care be implemented in the more extreme soils outside these texture classes. In addition, soil amelioration (liming) is always a compromise where we will rarely be able to adjust to the optimal conditions for the plant population and soil texture and at the same time pay attention to the economic costs and benefits of the soil amelioration (Foth, 1984).

The molecular weight of $\mathrm{CaCO}_{3}$ is $100.05 \mathrm{~g} / \mathrm{mol}$ and each mole carbonate neutralizes two $\mathrm{H}^{+}$equivalents which implies that we need $3 \mathrm{mmol} \mathrm{CaCO}_{3}$ being equal to $300 \mathrm{mg} \mathrm{CaCO}$ per $100 \mathrm{~g}$ soil or $3 \mathrm{~kg} \mathrm{CaCO} / 1000 \mathrm{~kg}$ soil. If we assume that the plough-layer contains $2000 \mathrm{t}^{\text {soil ha-1 }} \mathrm{he}^{-1}$ whould apply $6 \mathrm{t}$ lime ha-1 in order to raise the $\mathrm{pH}$ from 4.5 to 6.5 . Liming begins with the neutralization of $\mathrm{H}^{+}$in the soil solution (the active acidity) by adding a base (usually $\mathrm{CO}_{3}{ }^{2-}$ or $\mathrm{OH}^{-}$) originating from a natural source of lime material

The rate of the reaction is directly related to the rate at which the $\mathrm{H}^{+}$ions are neutralized in solution. As long as sufficient $\mathrm{CaCO}_{3}$ is available, $\mathrm{H}^{+}$will be converted to $\mathrm{H}_{2} \mathrm{O}$. The continued removal of $\mathrm{H}^{+}$from the soil solution will ultimately result in the precipitation of $\mathrm{Al}^{3+}$ as $\mathrm{Al}(\mathrm{OH})_{3}$ and replacement on the $\mathrm{CEC}$ with $\mathrm{Ca}^{2+}$. Thus, as soil $\mathrm{pH}$ increases, BS\% also increases. Practically, different approaches are available in order to predict the limestone rate required to attain an adequate level aiming to avoid Al toxicity towards plant growth. One of the methods for predicting the lime requirement is to monitor the evolution of exchangeable Al. The base enrichment especially of $\mathrm{Ca}^{2+}$ ions in this soil will neutralize exchangeable Al thus enhancing root growth (Franco and Munns, 1982; Bell and Bessho, 1993).

The most abundant liming materials are $\mathrm{Ca}$ and $\mathrm{Mg}$ oxides, hydroxides, carbonates, and silicates (Dick et al., 2000). The accompanying anion must neutralize $\mathrm{H}^{+}$in solution and hence $\mathrm{Al}^{3+}$ in solution and on the CEC. Other neutral salts that are not liming materials include $\mathrm{CaSO}_{4} \cdot 2 \mathrm{H}_{2} \mathrm{O}, \mathrm{MgSO}_{4} \cdot 7 \mathrm{H}_{2} \mathrm{O}, \mathrm{KCl}, \mathrm{CaCl}_{2}$, and $\mathrm{MgCl}_{2}, \mathrm{NaOH}$ could be considered a liming material except for addition of $\mathrm{Na}$ on the $\mathrm{CEC}$ which is not recommended due to the adverse effects of $\mathrm{Na}$ on soil physical properties (Basta, 2000).

Table 1. Basic properties of the most common liming materials ( $Q L, H L, D L$ and $L M)$.

\begin{tabular}{lllll}
\hline Lime material & $\begin{array}{l}\text { Molecular weight } \\
\text { (g/mole) }\end{array}$ & $\begin{array}{l}\text { Equivalent weight } \\
\text { (g/equivalent) }\end{array}$ & $\begin{array}{l}\text { Calcium carbonate } \\
\text { equivalent (CCE, \%) }\end{array}$ & $\begin{array}{l}\text { Ca-content } \\
\text { (\%) }\end{array}$ \\
\hline $\mathrm{CaO}$ & 56 & 28 & 179 & 71 \\
$\mathrm{Ca}(\mathrm{OH})_{2}$ & 74 & 36 & 135 & 54 \\
$\mathrm{CaMg}\left(\mathrm{CO}_{3}\right)_{2}$ & 184 & 46 & 109 & $22(13 \% \mathrm{Mg})$ \\
$\mathrm{CaCO}_{3}$ & 100 & 50 & 100 & 40 \\
\hline
\end{tabular}

Source Brady and Weil (2002). Expressed as a weight percentage of pure $\mathrm{CaCO}_{3}$.

Calcium Oxide $(\mathrm{CaO})$ is the only material to which the term lime may be correctly applied. Also known as unslaked lime, burned lime or quicklime, $\mathrm{CaO}$ is a white powder, shipped in paper bags because of its caustic properties (Chan and Heenan, 1998). It is manufactured by roasting $\mathrm{CaCO}_{3}$ in a furnace, driving off gaseous $\mathrm{CO}_{2}$. $\mathrm{CaO}$ is the most effective of all liming materials with a calcium carbonate equivalent (CCE) of $179 \%$, compared with pure $\mathrm{CaCO}_{3}$. If for some reason unusually rapid results are required, either $\mathrm{CaO}$ or $\mathrm{Ca}(\mathrm{OH})_{2}$ should be used. Calcium carbonate equivalents of liming materials (CCE), the value of a liming material depends on the quantity of acid that a unit weight of lime will neutralize, which is related to the chemical composition and purity (Dick et al., 2000). Pure $\mathrm{CaCO}_{3}$ is the standard against which other liming materials are measured, and its neutralizing value is considered to be $100 \%$. CCE is defined as the acid-neutralizing capacity of a liming material expressed as a weight percentage of $\mathrm{CaCO}_{3}$. Consider the following reactions:

$\mathrm{CaCO}_{3}+2 \mathrm{H}^{+} \leftrightarrow \mathrm{Ca}^{2+}+\mathrm{CO}_{2}+\mathrm{H}_{2} \mathrm{O}$

$\mathrm{Ca}(\mathrm{OH})_{2}+2 \mathrm{H}^{+} \leftrightarrow \mathrm{Ca}^{2+}+2 \mathrm{H}_{2} \mathrm{O}$

In each reaction, 1 mole of $\mathrm{CO}_{3}{ }^{2-}$ will neutralize 2 moles of $\mathrm{H}^{+}$. The molecular weight of $\mathrm{CaCO}_{3}$ is 100 $\mathrm{g} /$ mole, whereas that of $\mathrm{Ca}(\mathrm{OH})_{2}$ is only $74 \mathrm{~g}$ mole $^{-1}$; thus, $74 \mathrm{~g}$ of Ca $(\mathrm{OH})_{2}$ will neutralize the same amount of acid as $100 \mathrm{~g}$ of $\mathrm{CaCO}_{3}$ (Rengel, 2003). Wide amounts of PRs are added directly to soils mainly as a source of $\mathrm{P}$. Unlike high grade soluble P fertilizers, such as TSP, PRs can also have a liming value in addition to supplying P and $\mathrm{Ca}$ (Bolan et al., 2003). The liming action of PRs can occur through two processes. Firstly, most PRs contain some free $\mathrm{CaCO}_{3}$ which itself can act as a liming agent. Secondly, the dissolution process of the $\mathrm{P}$ mineral 
component (i.e., apatite) in soils consumes $\mathrm{H}^{+}$, thereby reducing the soil acidity. It is estimated that every $1 \mathrm{~kg}$ of $\mathrm{P}$ dissolved from PRs generates a liming value equivalent to $3.2 \mathrm{~kg} \mathrm{CaCO}$. The liming values of various PRs are varying from 450 to $560 \mathrm{~kg} \mathrm{CaCO}_{3}$ ton $^{-1}$ depending on their $\mathrm{P}$ and free $\mathrm{CaCO}_{3}$ content.

\section{Other liming materials}

Although the exact CCE or relative liming effect was not determined there were several inputs which are used to modify the soil $\mathrm{pH}$ with their chelating and buffering impacts beyond their soil ameliorating effects. dominantly known sources are biochar and organic fertilizer sources like compost, vermicompost and farm yard manures.

\section{Biochar as liming material}

Biochar is a wide range of materials produced from the thermal treatment of organic matter (usually plant material but sometimes municipal waste or animal manure) under reduced or zero oxygen D. S. Powlson, et al. (2011). It can be produced as a co-product of pyrolysis designed to produce liquid biofuels and local energy for heating. Biochar could potentially become available in large quantities and cheaply it is a very stable material, with lifetimes estimated to be in the range of centuries to millennia (Lehmann, 2007). Biochar has an alkaline $\mathrm{pH}$ that can act as a liming treatment with consequences for the cycling of Carbon and other essential nutrients. It is also necessary to investigate possible inputs and bioavailability of pollutants such as polyaromatic hydrocarbons that can be present in biochar. In addition to the possibility of direct impacts on SOC, there is evidence that addition of biochar to some soils increases retention of nutrients and water and improves soil physical characteristics and crop growth (Liang et al., 2006; Major et al., 2010; Sohi et al., 2010). If these effects are widespread they will, indirectly, contribute to climate change mitigation by decreasing the quantity of $\mathrm{N}$ fertilizer required to achieve a given yield.

Table 2. Fertility characteristics of Norfolk Ap soil + percent biochar mixtures on 0- and 67-day incubations (Mehlich 1 extractant)

\begin{tabular}{|c|c|c|c|c|c|c|c|c|c|c|c|c|c|}
\hline \multirow{3}{*}{$\begin{array}{l}\text { Norfolk Ap } \\
\text { soil + \% biochar }\end{array}$} & \multirow{3}{*}{$\frac{\text { Incubation }}{\text { day }}$} & \multicolumn{12}{|c|}{ Fertility characteristics ${ }^{\ddagger}$} \\
\hline & & $\mathrm{pH}^{\mathrm{s}}$ & CEC & Exch. acid & $\mathrm{Ca}$ & $\mathrm{Cu}$ & $\mathbf{K}$ & Mg & Mn & $\mathrm{Na}$ & $\mathbf{P}$ & $\mathbf{s}$ & $\mathbf{Z n}$ \\
\hline & & \multicolumn{3}{|c|}{ 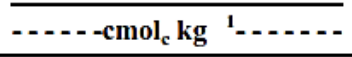 } & \multicolumn{9}{|c|}{ - } \\
\hline 0 & 0 & $4.8^{\mathrm{a}}$ & $5.7^{\mathrm{a}}$ & $2.4^{\mathrm{a}}$ & $437^{\mathrm{a}}$ & $0.6^{\mathrm{a}}$ & $35^{\mathrm{a}}$ & $117^{\mathrm{a}}$ & $12^{\mathrm{a}}$ & $5^{a}$ & $30.5^{\mathrm{a}}$ & $8.67^{\mathrm{a}}$ & $13^{\mathrm{a}}$ \\
\hline 0.5 & 0 & $5.1^{\mathrm{b}}$ & $5.3^{\mathrm{a}}$ & $2.0^{\mathrm{a}}$ & $470^{\mathrm{b}}$ & $0.7^{\mathrm{a}}$ & $49^{\mathrm{b}}$ & $98^{\mathrm{b}}$ & $7^{\mathrm{b}}$ & $5^{\mathrm{a}}$ & $30.8^{\mathrm{a}}$ & $7.67^{\mathrm{a}}$ & $12^{\mathrm{a}}$ \\
\hline 1.0 & 0 & $5.5^{\mathrm{c}}$ & $5.4^{\mathrm{a}}$ & $1.9^{\mathrm{a}}$ & $516^{\mathrm{c}}$ & $0.7^{\mathrm{a}}$ & $66^{\mathrm{c}}$ & $90^{\mathrm{c}}$ & $15^{\mathrm{c}}$ & $6^{\mathrm{a}}$ & $31.2^{\mathrm{a}}$ & $7.83^{\mathrm{a}}$ & $11^{\mathrm{a}}$ \\
\hline 2.0 & 0 & $6.3^{\mathrm{d}}$ & $5.9^{\mathrm{a}}$ & $1.2^{\mathrm{b}}$ & $720^{\mathrm{d}}$ & $0.8^{\mathrm{a}}$ & $111^{\mathrm{d}}$ & $91^{\mathrm{d}}$ & $10^{\mathrm{d}}$ & $7^{b}$ & $35.2^{\mathrm{b}}$ & $8.50^{\mathrm{a}}$ & $11^{\mathrm{a}}$ \\
\hline 0 & 67 & $5.2^{\mathrm{a}}$ & $5.2^{\mathrm{a}}$ & $2.4^{\mathrm{a}}$ & $392^{\mathrm{a}}$ & $0.6^{\mathrm{a}}$ & $26^{\mathrm{a}}$ & $93^{a}$ & $7^{\mathrm{a}}$ & $3^{\mathrm{a}}$ & $28.7^{\mathrm{a}}$ & $6.33^{\mathrm{a}}$ & $12^{\mathrm{a}}$ \\
\hline 0.5 & 67 & $5.6^{\mathrm{b}}$ & $5.4^{\mathrm{a}}$ & $2.1^{\mathrm{a}}$ & $462^{\mathrm{b}}$ & $0.7^{\mathrm{a}}$ & $47^{\mathrm{b}}$ & $91^{\mathrm{a}}$ & $6^{\mathrm{a}}$ & $5^{b}$ & $31.7^{\mathrm{b}}$ & $5.16^{\mathrm{a}}$ & $11^{\mathrm{b}}$ \\
\hline 1.0 & 67 & $5.9^{\mathrm{c}}$ & $5.6^{\mathrm{a}}$ & $2.0^{\mathrm{a}}$ & $537^{\mathrm{c}}$ & $0.7^{\mathrm{a}}$ & $49^{\mathrm{c}}$ & $92^{\mathrm{a}}$ & $16^{\mathrm{b}}$ & $4^{a}$ & $31.7^{\mathrm{C}}$ & $4.00^{\mathrm{b}}$ & $11^{\mathrm{b}}$ \\
\hline 2.0 & 67 & $6.4^{\mathrm{d}}$ & $5.9^{\mathrm{a}}$ & $1.5^{\mathrm{b}}$ & $692^{\mathrm{d}}$ & $0.8^{\mathrm{a}}$ & $69^{\mathrm{d}}$ & $89^{\mathrm{a}}$ & $10^{\mathrm{c}}$ & $4^{a}$ & $33.3^{\mathrm{d}}$ & $3.17^{\mathrm{c}}$ & $10^{\mathrm{c}}$ \\
\hline
\end{tabular}

${ }^{\dagger}$ Extracted with $\mathrm{H}_{2} \mathrm{SO}_{4}+\mathrm{HCl}$.

${ }^{\ddagger}$ Mean values sorted by incubation day were compared using a one-way ANOVA for multiple-comparisons tests vs. a control (Norfolk Ap soil + $0 \%$ biochar).

${ }^{\S}$ Means followed by a different letter are significantly different at $P<0.05$.

Source: Lippincott Williams \& Wilkins 2009

From these study results after adding $2 \%$ biochar were presented because this treatment caused the most significant soil fertility variations compared with the untreated soil. The treated Norfolk Ap soil $\mathrm{pH}$ was become suitable for most crop production after biochar addition through a 38\% reduction in monomeric Al species on exchange sites (lower exchangeable acidity values). Soil $\mathrm{Ca}$ and $\mathrm{K}$ concentrations had marked increases $(+58$ and $+106 \%$, respectively) implying that biochar additions can increase those essential nutrients (Lippincott et al. 2009). Likely study in southern acidic soil of Ethiopia showed that the application of biochar significantly reduced, soil bulk density and exchangeable acidity when compared with untreated ones (Abewa et al., 2013). Also, the total soil porosity, soil $\mathrm{pH}$, total nitrogen, soil organic carbon, available phosphorus, and potassium were significantly increased in the soil (Tariku B. et al., 2017). The addition of $12 \mathrm{t} \mathrm{ha}^{-1}$ of Lantana camara biochar reduced exchangeable acidity to $2.24 \mathrm{cmol}(+) \mathrm{kg}^{-1}$, comparatively from untreated entry which have exchangeable acidity result of $6.7 \mathrm{cmol}(+) \mathrm{kg}^{-1}$. similarly soil $\mathrm{pH}$ value increased by 0.5 and 1.5 units in all of the biochar treated soils.

\section{Vermicompost as acid soil amendment}

Soil organic matter or organic carbon concentration is firmly related to soil quality and vegetation productivity (Bruun T et al. (2012) which is due to several contributions to soil physical, chemical and biological properties like improvement of soil structure and water retention, provision of cation exchange capacity and supply of plant nutrients through mineralization (Lal, 2008). To improve SOC as well as an amendment of severe acidic 
properties of soil organic fertilizer sources like compost, vermicompost and farmyard manure were used. Among those common organic inputs vermicompost was known to have good soil $\mathrm{pH}$ improvement with best quality mineralized nutrient supplies like $\mathrm{NO}_{3}$.

Vermicompost is a product from biodegradation of organic matter through interaction between earthworms (mostly vermi-worm Eisenia fetida spps.) and microorganisms (Edwards et al., 1988). Vermicompost could be used as an excellent soil amendment for raising nursery species plants as well as for main fields. Vermicompost are characterized by high in porosity, drainage, water holding capacity and microbial activity which make them excellent soil conditioners for plant growth and development. These are rich source of nutrients such as nitrates, phosphates and exchangeable calcium and soluble potassium (Orozco et al., 1996).

The $\mathrm{pH}$ of vermicompost by itself varies depending on its sources of input and content of raw materials. For example, the $\mathrm{pH}$ of sheep manure vermicompost was 8.6 which is relatively greater than other vermicompost derived from organic sources Dhakal, Gyanendra. (2013). On the other hands vermicompost prepared from cattle manure had a pH 6.0 (Jordao et al., 2000) and 6.7 (Alves et al., 2001) whereas that derived from pig manure had pH 5.3 (Atiyeh et al., 2002) and 5.7 (Atiyeh et al., 2001). Vermicompost derived from sewage had pH of 7.2 (Masciandaro et al., 2000). These differences in $\mathrm{pH}$ are related to raw materials used for vermicomposting (Alves et al., 2001).

Study shows that phosphate activity obtained from vermicompost of cow dung was exhibited the highest acid phosphate activities (200.45 $\mu \mathrm{g}$ p-nitrophenol $\left.\mathrm{g}^{-1} \mathrm{~h}^{-1}\right)$ followed by vermicompost from grasses $(179.24 \mu \mathrm{g} \mathrm{p}$ nitrophenol $\mathrm{g}^{-1} \mathrm{~h}^{-1}$ ) and aquatic weeds (174.27 $\mu \mathrm{g}$ p-nitrophenol $\mathrm{g}^{-1} \mathrm{~h}^{-1}$ ) whereas alkaline phosphatase activity was highest in vermicompost obtained from aquatic weeds followed by cow dung and grasses $(679.88,658.03$ and $583.28 \mu \mathrm{g}$ p-nitrophenol $\mathrm{g}^{-1} \mathrm{~h}^{-1}$ respectively) which is without application of lime and microbial inoculation Vinotha et al. (2000). Related to soil acidity attributes vermicompost also had respectable response as reported by Wael et al. (2011) stated that vermicompost was used to increase the $\mathrm{pH}$ in acidic soils and reduce $\mathrm{Al}$ and $\mathrm{Mn}$ toxicity because of its alkalinity. Study in the western Ethiopia acidic soil showed that Vermicompost application at different application rate had gave significant effects (Abdissa et al., 2018), on soil acidity features like soil $\mathrm{pH}$, exchangeable acidity and soil acid saturation percentage which was positively affected like other soil physicochemical properties due to application of vermicompost which was prepared from most preferred raw materials.

\subsection{Research Achievements on Soil Acidity Management in Ethiopia}

The current acid soil management research in Ethiopia has two major strategies which cops with soil and cultivated crops (Temesgen et al., 2019). On the soil management part, it deals with different amendment practices like lime, biochar, organic fertilizer application and other practices which improve the productivity of such soils whereas the second strategies relays on the improvement of crops to cope with acidic soil condition recently both strategies were given due attention to alleviate productivity problem in such areas. The planting of acid tolerant crop species and varieties allows production to continue on the acidic soils but does not change the soil acidity status (Marschner, 1995; Somani, 1996). In many soils, the best results are obtained from the combined use of tolerance crop species and/or variety with the use of appropriate rates of lime. Whereas many plants can tolerate $\mathrm{pH}$ ranges of 5.2-7.8, most plants grow best in mineral soils when soil $\mathrm{pH}$ is between 6.0 and 7.0 .

Several research achievements were found in the use of lime with application of essential nutrient sources specially $\mathrm{p}$ fertilizers also on the use of integrated acid soil amendments like organic corrections to recover the productivity of acidic soil of the country (Getachew and Taye, 2005). With those research findings it's possible to confirm that adding lime or other liming materials can raise or moderate the soil $\mathrm{pH}$ to the optimal range for crop production, create an environment for the healthy functioning of microbes, and increase levels of calcium or magnesium ions (Abera, 1994).

\section{PHOSPHORUS IN SOIL AND ITS FUNCTION FOR PLANTS}

After nitrogen, phosphorus (P) has more widespread influence on both natural and agricultural ecosystems than any other essential plant element (Brady and Weil, 2002). It's classified as a macro nutrient because of the relatively large amount of $\mathrm{p}$ required by the. It contributes to numerous vital functions in plants such as photosynthesis, energy transfer, respiration, and cell division. Dissolution rates of $\mathrm{P}$ minerals differ depending on the soil reaction (Pierzynski et al., 2005; Oelkers and Valsami-Jones, 2008). There are several forms of P in the soil, which are in complex equilibrium with each other and can convert from stable to plant available forms (Shen et al., 2011). P is limiting factor to plant productivity on an estimated $40 \%$ of the world's arable soil. Phosphorus enhances a good development of the root system particularly of the fibrous and lateral rootlets, a route through which the other nutrients can be made available to plants.

Phosphorus is chemically reactive in soils and over 170 mineral forms (Holford, 1997), as well as many organic forms, have been identified. Inorganic P usually accounts for $35 \%$ to $70 \%$ of total $\mathrm{P}$ in soil (calculation 
from Harrison, 1987). Primary P minerals including apatite, strengite, and variscite are very stable, and the release of available P from these minerals by weathering is generally too slow to meet the crop demand though direct application of phosphate rocks (i.e. apatite) has proved relatively efficient for crop growth in acidic soils. phosphorus compounds formed depend on the chemistry of a particular soil, and the solubilization-precipitation reactions involving these compounds are strongly $\mathrm{pH}$-dependent.

Inorganic $\mathrm{p}$ entering the soil solution, by mineralization or fertilizer additions, is rapidly converted into less available forms. Sorption and precipitation reactions are involved. The sorption of inorganic $\mathrm{P}$ from solution is closely related to the presence of amorphous $\mathrm{Fe}$ and $\mathrm{Al}$ oxides and hydrous oxides and the amounts of $\mathrm{CaCO}_{3}$ (Bolt and Bruggenwert, 1978). Hydrous oxides and oxides of $\mathrm{Al}$ and $\mathrm{Fe}$ often occur as coatings on clay mineral surfaces, and these coatings may account for a large portion of the $\mathrm{P}$ sorption associated with the clay fraction of soils. Levels of P deficiency, sufficiency, and excess have been determined in solution culture and in greenhouse and field experiments. Total phosphorus content of a selected plant part at a certain growth stage is used for most crops. However, many standards developed for vegetable crops are based on a $2 \%$ acetic acid extraction (Allen and David, 2007). Diagnostic standards for Barley crop are summarized in Table 3 from research studies.

Table 3. Different levels of Phosphorus in Barley plat tissues on several plant growth stages GS.

\begin{tabular}{|c|c|c|c|c|c|c|c|}
\hline Species & $\begin{array}{c}\text { Growth } \\
\text { Stage }\end{array}$ & $\begin{array}{c}\text { Plant } \\
\text { Part }\end{array}$ & Deficient & Low & Sufficient & High & Reference \\
\hline \multirow{4}{*}{$\begin{array}{l}\text { Barley } \\
\text { (Hordeum } \\
\text { vulgare L.) }\end{array}$} & GS 2 & WP & $<0.30$ & & & & 130 \\
\hline & GS 6 & WP & $<0.30$ & $0.30-0.40$ & $>4.0$ & & 130 \\
\hline & GS 9 & WP & $<0.15$ & $0.15-0.20$ & $>0.20$ & & 130 \\
\hline & GS 10.1 & WP & $<0.15$ & $0.15-0.20$ & $0.20-0.50$ & $>0.5$ & 131 \\
\hline
\end{tabular}

Source: Allen and David (2007)

Phosphorus deficiency in crop plants is a widespread problem in various parts of the world, especially in highly weathered acidic soils. Worldwide applications of phosphate fertilizers now exceed over 48.2 million metric tons annually (FAO, 2019). The deficiency of this element is related to several factors (Epstein and Bloom, 2005). These factors are low natural level in some soils, high immobile or fixation capacity of acidic soils, uptake of modern crop cultivars in large amount, loss by soil erosion, and use of low rate by farmers in developing countries (Faye et al., 2006). Biotic stresses such as crop infestation of insects, diseases, and weeds also reduce $\mathrm{P}$ use efficiency in crop plants.

\subsection{Correlation Between Phosphorus and Soil Acidity}

Many acid soils are naturally low in phosphorus $(\mathrm{P})$ and require applications of $\mathrm{P}$ fertilizer to achieve economic yields. In addition, they are usually highly P-fixing (Marschner, 1995). When P fertilizers are applied to replenish soil fertility of these soils, about $70-90 \%$ of the $\mathrm{P}$ fertilizer is adsorbed and becomes locked in various soil P compounds (residual P) of low solubility without giving any immediate contribution to crop production (Holford, 1997). Acid soils with high P-fixing capacities are the Alfisols, Andosols, Oxisols, and Ultisols. Concentrations of inorganic $\mathrm{P}$ in the soil solution of many acid soils are low, typically $1-5 \mathrm{mmol} \mathrm{m}^{-3}$ or less, and even in fertile agricultural soils seldom exceed $10 \mathrm{mmol} \mathrm{m}^{-3}$ (Bieleski, 1973). Consequently, most acid agricultural soils require fertilizer $\mathrm{P}$ to provide soluble $\mathrm{P}$ close to the roots to meet plant requirements, (Sharpley, 1985; Mc Laughlin et al., 1988) but the recovery of this P by plants in the season of application is often only 10 to $20 \%$.

Different manures and fertilizers result in different pools of P (Schimidt et al., 1996) depending mainly on the rates of $\mathrm{P}$ applied, removal by crops, inherent soil properties, and climatic conditions. Furthermore, the solubility and type of fertilizers also determines the fractions and pools, because only a small proportion of the fertilizer has been found to dissolve in the soil (Perrott et al., 1992). Consequently, PRs are expected to exhibit higher residual effectiveness than triple super phosphate (TSP). Nevertheless, conflicting results have been reported; for instance, TSP was reported to be most effective in the year of application and declined at varying rates in different sites, while the PRs were less effective than TSP and effectiveness declined with increasing rates of application (Bolland and Gilkes, 1995).

\subsection{The Status of $P$ and Factors Affecting Its Availability on Acidic Soils of Ethiopia}

The main Essential nutrients that become depleted and therefore seriously limit soil productivity in Ethiopian crop production system are nitrogen and phosphorus (Duffera and Robarge, 1999). The relatively weathered red soils are limited more by a lack of phosphorus, Nationwide fertilizer trials with cereals have indicated that more than $25 \%$ of the soils are highly responsive to the addition of phosphorus, in addition the nutrient status of most soils is decreasing between $70 \%$ and $75 \%$ of the agricultural soils of the highland plateau area of Ethiopia are deficient in phosphorus. 
The solubility and availability of important nutrients to plants is closely related to the $\mathrm{pH}$ of the soil (Somani et al., 1996). The effects of high acidity in a soil cause a shortage of available P, Ca and Mo on the one hand, and an excess of soluble $\mathrm{Al}, \mathrm{Mn}$ and other metallic ions. In soil $\mathrm{pH} \mathrm{6-7,} \mathrm{P}$ fixation is low and its availability to plants is higher. This $\mathrm{pH}$ range seems to promote a ready availability of plant nutrients. Study on the two important plant growth limiting nutrients nitrogen and phosphorus shows that acid soils dominate most of the southern and south western parts of Ethiopia and generally have low P content (Hailu, 1998). Soils in the south and southwestern parts, including Sidamo, Illubabor and Keffa, have high N and low P contents.

\subsection{Phosphatic Fertilizer Sources and Type}

In organic or chemical fertilizers are typically less expensive (per unit of nutrient) and more readily available for plant growth than organic fertilizers (Osinama, 1995). However, organic fertilizers often supply other nutrients in addition to N-P-K, release nutrients slowly over the growing season and may double as soil conditioners. Inorganic $\mathrm{P}$ fertilizers come from phosphate rock (PR) which is a naturally occurring sedimentary rock composed largely of calcium phosphate minerals (apatite). Phosphate ores contain one or more phosphate minerals suitable for commercial use, such as fluorapatite $\left(\mathrm{Ca}_{5}\left(\mathrm{PO}_{4}\right)_{3} \mathrm{~F}\right)$. (IAEA, 2004) Hence, the mineralogy of phosphorus rich rocks is complex and there are more than 200 known phosphate minerals.

Phosphate ores are divided into three groups according to their $\mathrm{P}_{2} \mathrm{O}_{5}$ content: low-grade ores $(12-16 \%$ $\left.\mathrm{P}_{2} \mathrm{O}_{5}\right)$, intermediate grade ores $\left(17-25 \% \mathrm{P}_{2} \mathrm{O}_{5}\right)$, and high-grade ores $\left(26-35 \% \mathrm{P}_{2} \mathrm{O}_{5}\right)$. Deposits that could be mined and processed economically to give about 28-38\% $\mathrm{P}_{2} \mathrm{O}_{5}$ are considered commercial phosphate deposits (Sengul et al., 2006). However, phosphate rocks decomposition by sulfuric acid remains the most widely used method (Sinirkaya et al., 2014) and over 90\% phosphoric acid produced worldwide is manufactured by digestion of phosphate rocks with sulfuric acid (Calmanovici et al., 1997). The phosphate rocks are decomposed by sulfuric acid in the manufacturing units of phosphate fertilizers according to the following reaction (Becker, 1989):

$\mathrm{CaF}_{2} .3 \mathrm{Ca}_{3}\left(\mathrm{PO}_{4}\right)_{2}+10 \mathrm{H}_{2} \mathrm{SO}_{4}+20 \mathrm{H}_{2} \mathrm{O} \rightarrow 10 \mathrm{CaSO}_{4} \cdot 2 \mathrm{H}_{2} \mathrm{O}+6 \mathrm{H}_{3} \mathrm{PO}_{4}+2 \mathrm{HF}$

The phosphoric acid is further reacted with ammonia (ammoniation) to produce ammonium phosphate fertilizers such as diammonium phosphate (DAP) and mono-ammonium phosphate (MAP). Production of ammonium polyphosphate fertilizer (APP) requires dehydration and polymerization of phosphoric acid prior to ammoniation. This polymerization is accomplished by the dehydration of phosphoric acid (Calmanovici et al., 1997). The most common commercially available inorganic P fertilizers are DAP, MAP, and APP. These sources have the advantage of high-water solubility-

$(\geq 90 \%)$ and high plant food content (Pagliari et al., 2010). Rock products of $\mathrm{P}$ have wide variety (e.g. black rock phosphate, soft rock or colloidal phosphate, super phosphate (SP). Be aware that the touted "immediately available" nutrients may refer to only a small percentage of the whole, while the rest will be released slowly. Not considered organic if treated with a chemical to increase nutrient solubility (Kim, 1998). Phosphate fertilizer demand, includes $\mathrm{H}_{3} \mathrm{PO}_{4}$ the world fertilizer outlook regional and sub-regional share of world increase (phosphoric acid) base fertilizer demand + non- $\mathrm{H}_{3} \mathrm{PO}_{4}$ fertilizer demand. The non- $\mathrm{H}_{3} \mathrm{PO}_{4}$ fertilizer demand includes $\mathrm{P}_{2} \mathrm{O}_{5}$ in single super phosphate, direct application phosphate rock (DAPR), nitric acid-based phosphate fertilizers, etc. The world phosphate fertilizer demand increased from 41.7 in 2013 to 42.7 million metric ton in 2014 , at a growth rate of $2.4 \%$ according to FAO, (2014) and it will exceed 50 MT by the 2024 with these growth rate of demands. Consequently, efficient uses and looking for varied phosphatic sources which might be less exploited before and a means of recycle uses should be considered since the major resource is limited.

\subsection{Fate of Phosphorus Fertilizer Added to Soils}

The phosphate in fertilizers and manure is initially quite soluble and available, when the fertilizer or manure phosphate comes in contact with the soil, various reactions begin occurring that make the phosphate less soluble and less available. The rates and products of these reactions are dependent on such soil conditions as $\mathrm{pH}$, moisture content, temperature, and the minerals already present in the soil (Quang et al., 1996). As phosphate ions in solution slowly migrate away from the fertilizer particle, most of the phosphate will react with the minerals within the soil. Phosphate ions generally react by adsorbing to soil particles or by combining with elements in the soil such as $\mathrm{Ca}, \mathrm{Mg}, \mathrm{Al}, \mathrm{Fe}$ and forming compounds that are solids. The adsorbed phosphate and the newly formed solids are relatively available to meet crop needs (Zhang et al., 2011). Gradually reactions occur in which the adsorbed phosphate and the easily dissolved compounds of phosphate form more insoluble compounds that cause the phosphate to be become fixed and unavailable over time this results in a decrease in soil test $\mathrm{P}$.

In acidic soils the first products formed would be amorphous Al and Fe phosphates (Quang et al., 1996). The amorphous $\mathrm{Al}$ and $\mathrm{Fe}$ phosphates gradually change into compounds that resemble crystalline variscite (an $\mathrm{Al}$ phosphate) and strengite (an Fe phosphate). Each of these reactions will result in very insoluble compounds of phosphate that are generally not available to plants (Harrold et al., 2006). Reactions that reduce P availability 
occur in all ranges of soil pH but can be very pronounced in acidic soils (Morel et al., 1989). Adding to the active P pool through fertilization will also increase the amount of fixed P. Depleting the active pool through crop uptake may cause some of the fixed $\mathrm{P}$ to slowly become active $\mathrm{P}$. The conversion of available $\mathrm{P}$ to fixed $\mathrm{P}$ is partially the reason for the low efficiency of $\mathrm{P}$ fertilizers (Dolui et al., 1984). Most of the P fertilizer applied to the soil will not be utilized by the crop in the first season. Continued application of more $\mathrm{P}$ than the crops utilize increases the fertility of the soil, but much of the added $\mathrm{P}$ becomes fixed and unavailable.

The fixation capacity of a soil may also be indicative of possible adverse environmental effects. The $\mathrm{P}$ fixation in soils depends upon soil $\mathrm{pH}$, organic matter content and mineralogical constitution of the colloids. Owusu et al. (1989) studied the phosphate sorption characteristics of some Ghanaian soils and found that the phosphate sorption maxima were highly correlated with the soil properties in the order: $\mathrm{Al}_{2} \mathrm{O}_{3}$, clay content, free $\mathrm{Fe}_{2} \mathrm{O}_{3}$ and organic carbon. Soon (1990) studied the solubility and retention of phosphates in soils of north western Canada prairies and found that correlations showed between P sorption capacity and clay content. Alorganic matter complexes and amorphous iron oxides were significant (Palm et al., 2001). Maintaining soil pH between 6 and 7 will generally result in the most efficient use of phosphate.

\subsection{Properties of different specialized Phosphatic Fertilizer Products}

Different $\mathrm{P}$ specialty products are produced in the world fertilizer industry to meet specific requirements of different soil and crop types. Accordingly, some of the fertilizers fabricated for acid soils with different economical and additional ingredient to support productivity in such soil types. Which are differ by its acidulation level and incorporated liming materials with essential nutrients required for crop production on those acid soil prone areas. Some of common products includes partly acidulated rock phosphate, hyper organic phosphate and different blended fertilizer which granulated with calcium carbonate etc.

\subsubsection{Partly Acidulated Rock Phosphate (PARP)}

PARP has been considered to be a possible means of minimizing the P-fixing capacity of acid soils use of PARP is to economize on the cost of acid, by using less acid than the amount required to convert entire tricalcium phosphate of the rock to mono-calcium phosphate (Mclean and Ssali, 1977) their use can be best postulated under conditions of financial stringency for fertilizer use. Generally favorable plant response coupled with the economy of its production make partially acidulated rock phosphate as one of the most desirable ways of increasing the effectiveness of ground PRs and a possible alternative source of $\mathrm{P}$ to superphosphate for acid soils (Sinirkaya et al., 2014). For most crops the agronomic value of PAPRs depends on the availability to plants of P from both water-soluble $\mathrm{P}$ and $\mathrm{P}$ from unreacted $\mathrm{PR}$, which in turn depends on a combination of fertilizer, soil and plant factors.

The direct application of rock phosphate (RP) (granule or powder) without previous reaction with sulfuric and/or phosphoric acids may be a suitable, less-expensive, alternative to water-soluble P fertilizers. In addition, the slow solubilization of RP in acidic soils may also contribute to decrease environmental risks, such as the eutrophication of surface waters (He et al., 1999). PARP are suitable for direct application and are a possible alternative to more expensive soluble P fertilizers in agricultural fields (Hamadi et al., 2012). But the ability of the PRs to release phosphates in plant available forms depends on their particle size, chemical and mineralogical characteristics as well as the properties of the soil in which they are applied. Research has revealed that PAPR is as agronomically effective as superphosphate fertilizers on food crops (Chien et al., 2010) which have its own merit with respect to economic fertilizer production and environmental safety and also have its own role in reducing foreign exchange pressure on for sub Saharan countries like Ethiopia.

\subsubsection{Organic Hyper Phosphate (MOHP)}

Organic phosphate contains Coral Calcium, Phosphoric and Silicic acids that come from the dropping of sea birds, the remains of fish, seaweed, and various other kinds of minerals (http//: www. Menjingumine. com, 2017). Organic-phosphoric acid: About $70 \%$ of the citric acid is soluble and the rest of $\mathrm{P}$ is slowly released into the soil and constantly available in the soil. Continual $\mathrm{P}$ supply throughout plant growth period function cannot be found in chemical fertilizers such as superphosphate. Thus, organophosphates are proven to increase harvests compared to chemically treated phosphate fertilizers. Plants absorb organic phosphates very effectively because the phosphoric acid is absorbed at a lower temperature compared to other phosphoric acid fertilizers. The table below contains some comparison between the organic hyper phosphate fertilizers.

Table 4. Absorption and fixation properties of different phosphorus sources in comparisons.

\begin{tabular}{||l|l||l|l||}
\hline Phosphoric Acid Fertilizer & $\begin{array}{l}\text { Absorption } \\
\text { Temperature }\end{array}$ & $\begin{array}{l}\text { Absorption } \\
\text { Rate (\%) }\end{array}$ & $\begin{array}{l}\text { Fixation Rate } \\
\text { (\%) }\end{array}$ \\
\hline \hline Fused Phosphate & $17^{\circ} \mathrm{C}$ & $3-7$ & $88-95$ \\
Super Phosphate / Ammonium Phosphate & $10^{\circ} \mathrm{C}$ & $5-9$ & $90-97$ \\
Minjingu Organophosphate + & $4^{\circ} \mathrm{C}$ & $70-85$ & $15-30$ \\
Steamed bone meal & $6^{\circ} \mathrm{C}$ & $60-70$ & $15-25$ \\
\hline
\end{tabular}


The main component in organic phosphate is di-calcium phosphate, which has a low solubility and does not condense. This reduces problems caused by unstable densities.

Calcium is an element that is usually used in calcium containing fertilizers and tends to be washed away easily, however, coral calcium does not it also rapidly neutralize soil acidity; however, when included in organic phosphate, it promotes healthier soil and enhances safety for plants; Coral Calcium is sponge like in nature it is porous and holds moisture. It promotes microorganisms in the soil and the calcium contained in Coral Calcium does not chemically react with other components in soil, making it is easier for plants to absorb (http//: www. Menjingumine .com, 2017). Silicic acid contained in organophosphate is produced from organic matter and thus does not harden and is easily absorbed. Calcium silicic acid, which is usually used as silicic fertilizer, is made from non- organic matter, and its solubility is deferent. Silicic acid enhances CEC and increases soil fertility. Lack of Silicic acid decreases the effects of calcium, and increases the risk of disease.

Organic phosphate has high $\mathrm{P}$ content, quick and slow release component, citric soluble not water-soluble, guaranteed minimum $50 \%$ citric soluble, absorption starts at $4^{\circ} \mathrm{C}$, very low fixation rate, very low cadmium and other dangerous metals level. It also increases CEC and helps microorganisms to reproduce and reduce soil degradation, improves water and nutrient holding capacity, acts as fertilizer and soil conditioner, adds organic matter into the soil, better metabolism of nitrate in plants, more P over the growing period, stronger cell walls and therefore flavor enhancement, resistance to fungi and mold attack, more upright stems \& open leaves, enhanced photosynthesis, more fertile and viable seed production, increase in soil micro fauna, and longer shelf life of produce are the major advantages (http//:www.Menjingumine.com, 2017).

\subsubsection{Blended fertilizer products}

There are different kinds of blended fertilizer formulation depends on the soil type and crop nutrient requirements. OCP and NAFAKA products can be mentioned for acid soils. NAFAKA plus fertilizer are the complete planting fertilizer product of Menjingu mine and fertilizer LTD. Containing many essential nutrients and sufficient calcium oxide as remedy to acidic soil. The fertilizer contains organic phosphorus which is not prone to fixation for tropical crops; thus, the recommended rate of application varies from $50-100 \mathrm{~kg}$ acre $\mathrm{k}^{-1}$ depending on soil condition and crop requirements. NAFAKA plus fertilizer have eight essential nutrient sources including all macro and few micro essential nutrients. From primary macro nutrient nitrogen $9 \%, \mathrm{P}_{2} \mathrm{O}_{5} 16 \%$, and $\mathrm{K}_{2} \mathrm{O} 16 \%$ and it contains $\mathrm{CaO} 25 \%$, sulfur $5 \%$ and $\mathrm{MgO} 2 \%$ from secondary macro nutrients; whereas from micro nutrients it also has Zinc and Boron with $0.5 \%$ and $0.1 \%$ composition respectively. Its compound blended fertilizer with all nutrients in one granule which ensure uniformity in application of such fertilizer under field condition. Using such kinds of fertilizer with row planting method can utilize the fertilizer and liming material efficiency to the optimal.

\section{CONCLUSION}

A variety of solutions should be taken in account to adapt and mitigate soil fertility degradation specially soil acidity in Ethiopia, since it becomes a major limitation factor for agricultural productivities. Which can be done through multiple of approaches like developing and introducing acid soil tolerant crop species and varieties to adapt such harsh soil and environmental condition. On the other hands managing the soil with sustainable technologies is crucial with economic affordability for small scale farmers and environmental safety consideration.

Application of lime, biochar, organic fertilizers like farm yard manure and vermicompost where most commonly known acid soil amelioration option which modify the soil $\mathrm{pH}$ and supplement other essential nutrient for crop growth and productivity. From the most limiting nutrients which supply will be dependent on soil $\mathrm{pH}$ phosphorus is the major ones. Phosphorus fertilizer majorly found from rock phosphate (apatite) which become depleted within short period of time so efficient and sustainable use of such resource was vital. Direct application of rock phosphate or partly acidulated phosphate have an advantage of used as liming material through its mineralization process and $\mathrm{Ca}$ content which is found in rock phosphate. Beyond $\mathrm{N}$ and $\mathrm{P}$ other nutrient application becomes most important in Ethiopia soil fertility survey conducted in Ethiopia confirmed there was also deficiency of S, B, and Zn nutrients specially on acid soil so blending such essential nutrients with calcium carbonate will improve the application efficiency and affordability of both fertilizer and lime at ones. it also improves the loss of P fertilizer through high fixation capacity of acid soils with proper placements as well. Use of Organic sources of fertilizers integrated with efficient fertilizer should be considered.

\section{References}

Abdissa Bekele, Kibebew Kibret, Bobe Bedadi, Markku Yli-Halla, Tesfaye Balemi. 2018. Effects of Lime, Vermicompost, and Chemical P Fertilizer on Selected Properties of Acid Soils of Ebantu District, Western Highlands of Ethiopia", Applied and Environmental Soil Science, vol. 2018, Article ID 8178305.

Abera S. 1994. Review of industrial minerals in Ethiopia, pp 173-180, in: S.J. Mathers and A.J.G. Notholt (eds.), Industrial Minerals in Developing Countries. AGID Report Series Geosciences in International 
Development, 18: 35-58.

Abewa, A., Yitaferu, B., Selassie, Y. G., Amare, T. T. 2013. The role of biochar on acid soil reclamation and yield of Teff (Eragrostis tef [Zucc] Trotter) in Northwestern Ethiopia. J. Agric. Sci. 6. DOI: 10.5539/jas. V. 6.

Allen V.B. and David J.P. 2007. Handbook of plant nutrition by Taylor \& Francis Group, LLC. Boca Raton, London, New York, 1937: 51-90.

Alves, M.R., Landgraf, M.D., Resende, M.O. 2001. Absorption and desorption of herbicide alaclor on humic acid fractions obtained from two vermicompost, Journal of Environmental Science Health 36, 797- 808.

Ana Paula, Bettoni Teles, Marcos Rodrigues and Paulo Sergio Pavinato. 2020. Solubility and Efficiency of Rock Phosphate Fertilizers Partially Acidulated with Zeolite and Pillared Clay as Additives, Agronomy, 10, 918; doi:10.3390/agronomy 10070918,

Atiyeh, R.M., Arancon, N., Edwards, C.A., Metzger, J.D. 2000. Influence of earthworm-processed pig manure on the growth and yield of greenhouse tomatoes. Bioresource Technology 75, 175-180.

Atiyeh, R.M., Arancon, N.Q., Edwards, C.A., Metzger, J.D. 2002. The influence of earthworm-processed pig manure on the growth and productivity of marigolds. Bioresource Technology 81, 103-108.

Basta N.T. 2000. Examples of case studies of beneficial reuse of municipal by-products. In "Land application of agricultural, industrial, and municipal by-products" (W. A. Dick, Ed.), Soil Sci. Soc. Am, Madison, WI. 64: 481-504.

Becker P. 1989. Phosphates and Phosphoric Acid, Fertilizer Science and Technology Series Marcel Dekker. New York. Vol. 6.

Bell L.C. and Bessho T. 1993. Assessment of aluminum detoxification by organic materials in an Ultisol, using soil solution characterization and plant response. in: K. Mulongoy and R. Merckx (eds.). Soil organic matter dynamics and sustainability of tropical agriculture. p. 317-330. A Wiley-Sayce Co-Publication.

Bieleski R.L. 1973. Phosphate pools, phosphate transport, and phosphate availability, Annual Rev Plant Physiol, 24: $225-252$

Bolan N.S. Adriano D.C. and D. Curtin. 2003. Soil acidification and liming interactions with nutrient and heavy metal transformation and bioavailability, Fertilizer and Lime Research Centre, Massey University, Palmerston North, New Zealand. Adv. Agron., 78: 215-272.

Bolan N.S. and Hedley M.J., 2001. Role of carbon, nitrogen and sulfur cycles in soil acidification. In "Handbook of Soil Acidity" (Z. Rengel, Ed.), Marcel Dekker, New York. (Z. Rengel, Ed.), 29-56.

Bolan N.S., Hedley M.J. and Loganathan P. 1993. Preparation, forms and properties of controlled-release phosphate fertilizers. Fertilizer Research. Marcel Dekker, New York.

Bolt G.H. and Bruggenwert M.G. 1978. Soil Chemistry.2nd ed. Department of Soil Science and Plant Nutrition, Agricultural University of Wageningen. The Netherlands.

Brady N.C. and Weil R. R. 2002. The Nature and Properties of Soils. 13th ed. Prentice Hall, Upper Saddle River, New Jersey.

Bruun T. B., B. Elberling, A. De Neergaard And J. Magid. 2012. Organic Carbon Dynamics in Different Soil Types After Conversion of Forest to Agriculture. Department of Plant and Environmental Sciences, University of Copenhagen, DOI: 10.1002/ldr.2205.

Calmanovici C.E., Gilot B. and Laguérie C., 1997. Mechanism and kinetics for the dissolution of apatitic materials in acid solutions. Braz. J. Chem. Eng. 14 (2) http://dx.doi.org/10.1590/ S01046321997000200001. Accessed on 12-July 2019.

Carson C.D. and Dixon J.B., Acidity. 1979. The Encyclopedia of Soil Science. Pennsylvania: Hutchinson \& Ross Inc. (R. W. Fairbridge and C. W. Finkl, Eds.), 1-23.

Chan K.Y. and Heenan D.P. 1998. Effect of lime $\left(\mathrm{CaCO}_{3}\right)$ application on soil structural stability of a red earth. Aust. J. Soil Res. 36: 73-86.

Chien S.H., Prochnow L.I. and Mikkelsen R. 2010. Agronomic Use of Phosphate Rock for Direct Application. Better Crops. 94: 21-23.

D. Cordell, J. O Drangert, and S. White. 2009. The story of phosphorus: Global food security and food for thought. Global Environmental Change, 19(2):292.

D. S. Powlson, A. P. Whitmore and K. W. T. Goulding. 2011. Soil carbon sequestration to mitigate climate change: a critical re-examination to identify the true and the false. European Journal of Soil Science, 62, $42-55$.

Dhakal, Gyanendra. 2013. Effect of vermicompost on soil properties, growth, yield and disease control of tomato (Lycopersicum esculentum L) A Review.

Dick W.A., Stehouwer R.J., Wolfe W.E., Hao Y., Adriano D.C., Beeghly J.H. and Haefner R.J. 2000. Beneficial uses of flue gad desulphurization by-products: Examples and case studies of land application. In "Land Application of Agricultural, Industrial, and Municipal By-products" (W. A. Dick, Ed.). Soil Sci. Soc. Am, Madison, WI. 505-536. 
Dolui A.K. and Gangopadhyay S.K. 1984. Fixation of phosphate in relation to properties of some red and lateritic soils of West Bengal. Indian J. Agric. Chem. 17: 177 - 182,

Duffera M. and Robarge W.P. 1999. Effect of soil management practices on phosphorus sorption characteristics of the highland plateau soils of Ethiopia. Soil Sci. Soc. of Am. Journal, 63: 1455-1462.

Edwards, C.A. and I. Burrows, 1988. The potential of earthworm composts as plant growth media in Neuhauser, C.A. (Ed.), Earthworms in Environmental and Waste Management. SPB Academic Publishing, The Hague, the Netherlands, pp: 211-220.

Epstein E. and Bloom A.J. 2005. Mineral Nutrition of Plants: Principles and Perspectives. 2nd Edition. Sinauer Associates, Sunderland.

EthioSIS (Ethiopia Soil Information System). 2014. Ethiopian Agricultural Transformation Agency. Available at: http://www.ata.gov.et/projects/ethiopian-soil-information-system ethiosis. Accessed on 22 June 2020.

Fageria N.K. and Baligar V.C. 2003. Fertility management of tropical acid soils for sustainable crop production. In "Handbook of soil acidity" (Z. Rengel, Ed.). pp. 359-385. Marcel Dekker, New York.

Fageria N.K., Baligar V.C. and Zobel R.W. 2007. Yield, nutrient uptake, and soil chemical properties as influenced by liming and boron application in common bean in a no-tillage system. Commun. Soil. Sci. Plant Anal. 38: 1637-1653.

FAO (Food and Agriculture Organization of The United Nations), 2019. World fertilizer trends and outlook to 2022. Rome, ISBN 978-92-5-131894-2.

FAO. FAO-UNESCO, 1988. Soil map of the world. Revised legend, world soil resource report 60. Food and agricultural organization of United Nation, Rome.

Faye I., Diouf O., Guisse A., Sene M. and Diallo N. 2006. Characterizing root responses to low phosphorus in pearl millet [Pennisetumglaucum (L.) R. Br.]. Agron. 63.

Fenton G. and Helyar K. 2007. Soil acidification. In Peter E.V Chairman and Brian W Murphy (eds). Soils-Their Properties and Management. 3rd edition. Oxford University Press, Melbourne.

Foth H.D. 1982. Fundamentals of Soil Science. John Wiley and Sons, Inc. NY, USA, 1984.

Franco A.A. and Munns D.N., Acidity and aluminum constraints on nodulation, nitrogen fixation, and growth of Phaseolus vulgaris in solution culture. Soil Sci. Soc. Am. J. 46: 296- 301.

Getachew Agegnehu and Taye Bekele. 2005. On-farm integrated soil fertility management in wheat on Nitisols of Central Ethiopian highlands. Ethiopian Journal of Natural Resources, 7: 141-155.

Gutiérrez-Miceli F., J. Santiago-Boraz, JAM. Molina, C.C. Nafat, M. Abdul Archila, M.A.O. Llaven, R. RincónRosales and L. Dendooven. 2007. Vermicompost as a soil supplement to improve growth, yield and fruit quality of tomato (Lycopersicum esculentum). Bioresour. Technical., 98:2781-2786, Cited by Jordao, C.P., Pereira, M.G., Einloft, R., Santana, M.B., Bellato, C.R., Vargas de.

Hailu Regassa. 1998. Fertiliser recommendation for major crops. in: Proceedings of the First National Fertilizer Workshop, National Fertiliser Industry Agency, 15-18 October 1998, Addis Ababa, Ethiopia.

Hamadi A.S., Remedhan S.T. and Ali H.A. 2012. Phosphate rock treatment with hydrochloric acid for increasing P2O5 content, Eng. And Tech Journal. 30: 67-76.

Harrold S.A. and Tabatabai M.A. 2006. Release of inorganic phosphorus from soils by low-molecular-weight organic acids. Commun. Soil Sci. Plant Anal. 37: 1233-1245.

Haynes R.J. and Ludecke T.E. 1984. Yield root morphology and chemical composition of two pasture legumes as affected by lime and $\mathrm{p}$ application to an acid soil. Plant and soil. 62: 241-254.

Haynes R.J. and Naidu R. 1998. Influence of lime, fertilizer and manure applications on soil organic matter content and soil physical conditions. A review: Nutr Cycl Agroecosyst 51:123-137.

Holford I.C. 1997. Soil phosphorus: its measurement and its uptake by plants. Aust. J. Soil Sci. 15: $795-803$.

Hornick S.B. and Parr J.F. 1987. Restoring the productivity of marginal soil with organic amendment. Am. J. Alternative agriculture.

IAEA (International Atomic Energy Agency). 2004. International Labour Office, Occupational Radiation Protection in the Mining and Processing of Raw Materials. IAEA Safety Standards Series No.RS-G-1.6, IAEA, Vienna.

IFA (International Fertilizer Industry Association). 1992. World Fertilizer Use Manual. Paris. 632.

Jarvie, H.P., Sharpley, A.N., Flaten, D., Kleinman, P.J.A., Jenkins, A., Simmons, T., The pivotal role of phosphorus in a resilient water-energy-food security nexus. J. Environ. Qual., 44, 1049-1062, 2015.

Kim Howard T. 1998. Principle of soil chemistry. 3rd ed. Marcel Dekker, Inc. 270 Madison Avenue, New York, NY.

Lal R. 2008.Carbon sequestration in soil. CAB Reviews. Perspectives in Agriculture, Veterinary Science, Nutrition and Natural Resources 3:1-20.

Lehmann, J., 2007. A handful of carbon. Nature, 447, 143-144.

Liang, B., Lehmann, J., Solomon, D., Kinyangi, J., Grossman, J., O’Neill, B. 2006. Black carbon increases cation exchange capacity in soils. Soil Science Society of America Journal, 70, 1719-1730. 
M. N. Wael, V. R. Leon, C. Sarina, and B. Oswald. 2011. "Effect of vermicompost on soil and plant properties of coal spoil in the Lusatian region (Eastern Germany)," Karl-Liebknecht Strasse, vol. 24-25, p. 14476.

Major, J., Rondon, M., Molina, D., Riha, S.J. \& Lehmann, J. 2010. Maize yield and nutrition during 4 years after biochar application to a Colombian savanna oxisol. Plant \& Soil, 333, 117-128.

Marschner H. 1995. Mineral Nutrition of Higher Plants. Institute of Plant Nutrition, University of Hohenheim/Academic Press/Harcourt Brace, London, UK. 155.

Masciandaro, G., Ceccanti, B., Ronchi, V., Bauer, C. 2000. Kinetic parameters of dehydrogenase in the assessment of the response of soil to vermicompost and inorganic fertilizers. Biology and Fertility of Soils $32,479-483$.

McLaughlin M.J., Alston A.M. and Martin. 1988. Phosphorus cycling in wheat-pasture rotations. III. Organic phosphorus turnover and phosphorus cycling. Aust. J. Soil Res. 26: 323-331.

McLean E. and Ssali H. 1977. Effects of phosphorus rate and form in combination with lime and gypsum on yields and composition of German millet and alfalfa from highly weathered soils; Soil Sci. 123: 155-164.

Morel J.L., Fardeau J.C., Beruff M.A. and Guckert A. 1989. Phosphate fixing capacity of soils: a survey using the isotopic exchange technique of soils from north-eastern France. Fert. Res. 19: 103-111.

Oelkers E. H., and E. Valsami-Jones. 2008. Phosphate mineral reactivity and global sustainability. Elements. 4:83-87.

Orozco, S.H., J. Cegarra, L.M. Trujillo and A. Roig. 1996. Vermicomposting of coffee pulp using the earthworm Eisenia fetida: Effects on $\mathrm{C}$ and $\mathrm{N}$ contents and the availability of nutrients. Biol. Fertile. Soils. 22: 162-166.

Osinama O.A., 1995. Evaluation of three P sources for maize in south western Nigeria. Tropical Agriculture. 62: 33-37.

Owusu B.E. and Acquaye D.K. 1989.Phosphate sorption characteristics of selected major Ghanaian soils. Soil Sci. V. 6.

Pagliari P., Rosen C., Strock J. and Russelle M. 2010. Phosphorus availability and early corn growth response in soil amended with turkey manure ash. Communications in Soil Sci. and Plant Analysis. 41: 1369-1382.

Pagliari, P.H., Strock, J.S., Rosen, C.J., 2010. Changes in soil pH and extractable phosphorus following application of Turkey manure incinerator ash and triple superphosphate. Commun. Soil Sci. Plant Anal., 41, $1502-1512$.

Palm A.C., Gachengo C.N., Delve R.J., Cadisch G. and Giller K.E. 2001. Organic inputs for soil fertility management in tropical agroecosystems: Application of an organic resource database. Agriculture Ecosystems and Environment. 83: 27-42.

Perrott K.W. 1992. Effect of exchangeable calcium on fractionation of inorganic and organic soil phosphorus. Comuc. in soil sci. and plant analysis. New Zealand Journal of Agricultural Research 35: 307-319.

Pierzynski G. M., R. W. McDowell, and J. T. Sims. 2005. Chemistry, cycling, and potential moment of inorganic phosphorus in soils. In: Phosphorus: Agriculture and the Environment. Sims J. T. (ed.). American Society of Agronomy, Science Society of America, Soil Science Society of America, Inc., Madison, WI, pp. 53-86.

Poll, E and C.F Konzak. 1985. A single scale for Al tolerance in cereals, Agron. Abstr. 77th Annu. Meet Chicago, Ill. Am. Soc. Agron, Madison, wis.p.67.

Quang V.D., Thai V.C., Linh T.T. and Dufey J.E. 1996. Phosphorus sorption in soils of the Mekong Delta (Vietnam) as described by the Langmuir equation. Eur. J. Soil Sci.

Rajput, A., Panhwar, Q.A., Naher, U.A., Rajput, S., Hossain, E., Shamshuddin, J. 2014. Influence of incubation period, temperature and different phosphate levels on phosphate adsorption in soil. Am. J. Agric. Biol. Sci. 9, 251-260.

Rengel Z. 2003. Handbook of soil acidity. Marcel Dekker, New York.

Roberts, T.L., Johnston, A.E. 2015. Phosphorus use efficiency and management in agriculture. Resour. Conserv. Recy., 105, 275-281.

Schimidt J.P., Buol S.W. and Kamprath E.J. 1996. Soil phosphorus dynamics during seventeen years of continues cultivation: fractional analysis. Soil sci. soc. of Am. J. Vol. 60.

Schlede H. 1989. Distribution of acid soils and liming materials in Ethiopia. Note No. 326. Ethiopian Institute of Geological Survey, Addis Ababa, Ethiopia.

Sengul H., Ozer A.K. and Gulaboglu M.S. 2006. Benefication of Mardin Mazidagi Calcareous phosphate rock using dilute acetic acid solutions. Chem. Eng. J. 122, 135-140, http://dx.doi.org/10.1016/j.cej. accessed on 17 Feb. 2018.

Sharpley A.N. 1985. Phosphorus cycling in unfertilized and fertilized agricultural soils. Soil Sci. Soc. Am. J. Vol. 49.

Shen J., L. Yuan, J. Zhang, H. Li, Z. H. Bai, X. Chen, W. Zhang, and F. Zhang. 2011. Phosphorus dynamics: From soil to plant. Plant Physiol. 156:997-1005.

Sinirkaya M., Ozer A.K. and Gülaboglu M.S. 2014. Investigation of the solubilities of sulfated and ground phosphate rock after sulfation in H2SO4 solution. Pamukkale Univ. J. Eng. Sci. 20 (7): 253-257. 
Sohi, S.P., Krull, E., Lopez-Cappel, E. \& Bol, R. 2010.A review of biochar and its use and function in soil. Advances in Agronomy, 105,47-82.

Somani L.L. and Totawat K.L. 1996. Soil Conditioners and Amendments. Agro-tech Publishing Academy,

Tariku Berihun, Muluken Tadele and Firew Kebede. 2017. The application of biochar on soil acidity and other physico - chemical properties of soils in southern Ethiopia, Department of Biology, Dilla University, J. Plant Nutr. Soil Sci. 2017, 000, 1-8.

Temesgen Desalegen, Dejene Abera, Solomon Indris, Wondimu Tolcha and Tilahun Hordofa (eds.). 2019. Proceedings of the Natural Resources Management Research completed Research activities Workshop. November 25-26, at EIAR-HQ, Addis Ababa, Ethiopia.

Uexkull V.H. and Mutert E. 1995. Global extent, development and economic impact of acid soils. Plant Soil, 171: $1-15$.

USGS (United States Geological Survey), Minerals Yearbook: Phosphate Rock [Advance Release]. 2015. Available online: https://minerals.usgs.gov/minerals/pubs/commodity/ phosphate_rock/myb1-2015-phosp. (accessed on Jan. 2021).

Valentin C., Hoogmoed W. and Andriesse W. 1991. The maintenance and enhancement of low fertility soils: In proceeding of the international workshop on evaluation of sustainable land management in the developing world, Chang Rai, Thailand, 219-252.

Vinotha, S.P., K. Parthasarathi and L.S. Ranganathan. 2000. Enhanced phosphatase activity in earthworm casts is more of microbial origin. Current Science, 79: 1158-1159,

Zhang, L.M., Hu H.W., Shen J.P. and He Q.Z. 2011. Ammonia-oxidizing archaea have more important role than ammonia-oxidizing bacteria in ammonia oxidation of strongly acidic soils. 